\title{
The Students' Needs in Maritime English Class at Ami Aipi Makassar, Indonesia
}

\author{
Nur Aeni \\ Akademi Maritim Indonesia AIPI Makassar, Indonesia \\ Baso Jabu \\ Universitas Negeri Makassar, Jln. Bonto Langkasa, Kampus Gunung Sari, Makassar, South Sulawesi, Indonesia \\ Muhammad A. Rahman \\ Universitas Negeri Makassar, Jln. Bonto Langkasa, Kampus Gunung Sari, Makassar, South Sulawesi, Indonesia \\ Hamid Ismail \\ STKIP Kie Raha, Ternate, Indonesia \\ Saidna Z. Bin-Tahir \\ Universitas Iqra Buru, Maluku, Indonesia
}

\begin{abstract}
This paper reports the students' needs in developing a GME instructional course with the following research questions: 1) What is the present level of students' oral communication apprehension? 2) What are the students' needs (the learning and the language needs) in learning General Maritime English? The research was conducted at the Akademi Maritim Akademi Indonesia AIPI Makassar. There were 150 students of the nautical department in the academic year 2016-2017 as the primary subjects of this research. The researchers administered questionnaires, conducted interviews and observed exams to collect the data. The results found that the students' level of oral communication apprehension was high, based on the Foreign Language Classroom Anxiety Scale (FLCAS). It was also found that there was a high demand for materials that could prepare the students to have good communication skills, in order to be equipped to work in international maritime industries. Most of the students assumed that the four language skills (listening, speaking, reading, and writing) in English are crucial, but they placed productive skills (writing and speaking) as their highest priority. It is concluded that the results of this investigation should be taken into account in developing teaching and learning materials for maritime academy students.
\end{abstract}

Index Terms - students' needs, students' level of oral communication apprehension, Maritime English (ME), International Maritime Organization (IMO), Akademi Maritim Indonesia (AMI AIPI)

\section{INTRODUCTION}

Related to the Indonesian government's goal for seafarers to speak English fluently, lecturers have a need to use textbooks or materials which are suitable for the students' needs and that ensure speaking activities are dominant. Since it is an international curriculum, each educational institution must modify their current materials so that this goal can be achieved.

As such, the limited and irrelevant GME (General Maritime English) materials in Indonesia are becoming a hindrance in the process of teaching and learning to achieve the goals in the IMO (International Maritime Organization). Previous research has shown that this has caused an adverse effect on the students. Some of them are less motivated to learn English and their vocabulary is limited to the technical vocabulary related to their major as seafarers (Dirgayasa, 2014; Aini, 2017; Bin-Tahir et al., 2017). As a consequence, they will find it difficult when they are communicating with international staff on board in the future.

Specifically, in AMI AIPI Makassar the IMO Course 3.17 is used as a guidebook in teaching which has been widely recognized as needing to be modified, or replaced, based on the students' needs and characteristics. Based on this objective, the researcher intended to do some investigation on the learning needs of maritime students, especially for the nautical department.

\section{LITERATURE REVIEW}

\section{A. English for Specific Purposes}

Robinson (1991) defined that English for Specific Purposes (ESP) are generally constrained by a limited time period in which their objectives have to be achieved and are taught to adult in homogenous class in terms of work that the 
students are involved. ESP teaching should always reflect the underlying concept and activities of the discipline. The ESP is designed to meet the specific needs of the students, it is centered on the language (grammar, lexis, register), skills, discourse and genres appropriate to these activities.

In addition, ESP is designed for specific discipline, it may use in specific teaching situations, a different methodology from General English. ESP is likely to be designed for adult learners, either a tertiary level institution or in a professional work situation; it could be used for learners at secondary school level; most ESP courses assume basic knowledge of the language system, but it can be used with beginners.

Finally, the ESP curriculum and its syllabus have to be a learner-centered, which means all the teaching and learning activities are focused on the learners' needs and progress or achievement. The ESP teachers are true facilitators who are expected to facilitate learning and not only lecturing,

\section{B. Maritime English}

According to the International Maritime Organization (IMO) (2015), Maritime English has two main courses namely; General Maritime English (GME) and Specialized Maritime English (SME). There are two sections in the course model for General Maritime English: Core Part 1 and 2, both of which contain separate syllabus. This system allows students to enter the classroom at a point corresponding to their English level. It is recommended that the instructor perform a pre-course assessment to assess the level of language that is present of each student. The syllabus in Core 1 is designed for students who have the lower level of English while the syllabus in Section Core 2 is designed for students who have lower secondary or Middle English level. The definition of language level and entry requirements required for students/cadets is given in part A of both sections of the course.

For effective language teaching to take place, lecturers/ instructors need an understanding of the Communicative Approach methodology to be able to create tasks appropriate to their students' learning needs, to develop the students' communicative competence and to implement a syllabus that meets the requirements defined by the STCW Code.

\section{Students' Needs}

Communication needs lead the way when it is believed that what is taught to students must be in accordance with what they will need to apply, and therefore, it must determine the course content of ESP (Munby, 1978). The definition of 'needs' depends on the perception of those making the judgement. The difference between what learners can presently do with the language and what they should be able to do cannot be looked at from one standpoint.

In order to get and to know the students' needs, the researcher need to conduct need analysis as the activities involved in gathering information that will serve as the basis for developing a curriculum, syllabus, and course materials which meet the learning and language needs. Once identified, it can be stated in terms of goals and objectives which can serve as the bases for developing tests, materials, teaching activities, and evaluation strategies.

\section{Students' Level of Oral Communication Apprehension}

Leary (2013) has categorized three levels of apprehension, namely: low, moderate, high. Low anxiety relates to difficult situations happening in daily life. Low apprehension can motivate learning. The symptoms of low anxiety can be exhaustion, irritability, or ability to learn, depending on the situation. Meanwhile, moderate or reasonable apprehension can enable someone to focus on the crucial problem and turn aside from other problems (Salikin et al., 2017; Panggua, 2017). At this level of apprehension, symptoms include the faster heartbeat, quicker breathing, quicker speaking with a higher volume, and can cause decreasing concentration, so it is easy to forget something, become angry or cry.

The next level is high apprehension, which hugely reduces someone's perception. Someone with high-level trepidation tends to focus on details. Someone who is on this level of anxiety needs more guidelines to focus on the topic. Symptoms include headaches, insomnia, and ineffective learning. Critically, their fear can prevent them from saying anything at all.

Horwitz (1978) states that the level of oral communication apprehension/anxiety is based on the result of Foreign Language Classroom Anxiety Scale (FLCAS). To determine a student's anxiety level, add up their responses to all the questions, remembering to first reverse-score the items that need reverse-scoring, then divide the total by 33 (the total number of questions). Students with averages around 3 should be considered slightly anxious or moderate level, while students with averages below 3 are probably not very anxious or low level. Students who average near 4 and above are fairly anxious or high level. Ortega (2013) also states that foreign language anxiety is occurring when people feel confused, freeze up, and cannot say anything in speaking foreign language.

In conclusion, the researcher applied Horwitz scale as the guidance to determine the cadets or students' level of oral communication apprehension/ anxiety because it is not difficult to apply. It is measurable as well.

\section{E. Akademi Maritim Indonesia AIPI Makassar}

According to the Ministerial decision of Transportation Ministry No. 28, 2010, Akademi Maritim Indonesia (AMI) AIPI is an educational institution which offers vocational education programs in the maritime field. There are three departments, namely: deck, engineering, and port and shipping management. In this institute, the graduates from deck and engine departments receive a Diploma III certificate. In addition, the graduates from deck and engine departments 
receive a certificate of nautical/ technical class III. Then, they may also pass several training certifications to become a seafarer according to IMO requirements.

Akademi Maritim Indonesia (AMI) AIPI Makassar is an educational institution which holds such a vocational education program. Its curriculum is based on the IMO Model course. The characteristics of the learners of Indonesian Maritime Academy AIPI Makassar are various. Therefore, the researcher conducted needs analysis as one of steps to know better who the students are and what materials would be most appropriate for them to achieve communicative competence in English relevant to their field.

\section{METHOD}

This research investigated the students' needs by an applied survey method. Interviews were conducted and a questionnaire was distributed to students, lecturers, and alumni. There were two questionnaires used in this research, namely: the Needs Analysis Questionnaire and the Foreign Language Classroom Anxiety Scale (hereafter referred to as FLCAS, adapted from Horwitz, 1988). The data sources were multiple, by involving students, lecturers, and the employees from marine or nautical department. Purposive sampling was adopted. There were 150 students from the first semester of Akademi Maritim Indonesia (AMI) AIPI Makassar involved for this research to gather information about the present situation (the students' level of oral communication apprehension), the students' needs, the existing materials that they used during learning general maritime English course, and their expectations of the course. They all were given the questionnaire to fill in as well as 5 alumni who have worked in the International trade or company. Data were analyzed using the descriptive statistical method.

\section{RESULTS AND DisCUSSION}

\section{A. Results}

1). The students' level of oral communication apprehension

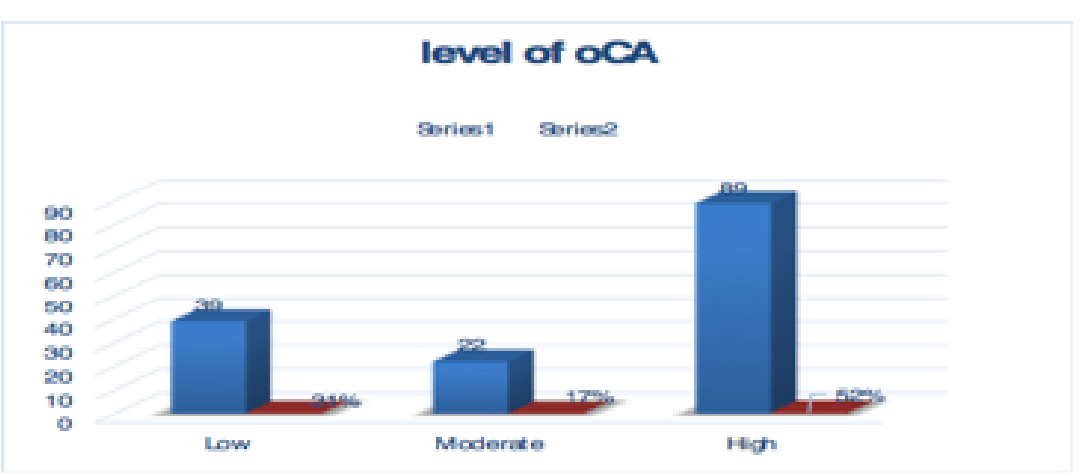

The FLCAS result showed that the students of the nautical department had a high apprehension level. 89 students felt anxiety in their English class especially when they had an upcoming speaking activity. Many reported trembling beforehand. This phrase refers to the analysis of students' present situation, students' proficiencies and difficulties to English language skills, students' needs, the existing materials, the objectives of learning English as General English course as well as the identification of the results of the analysis.

2). The frequency of students practicing English language skills

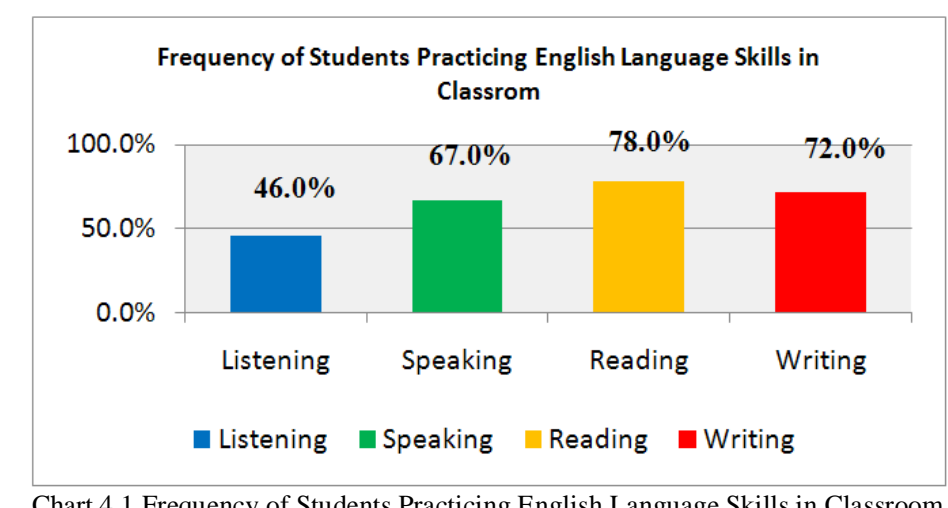

Chart 4.1 Frequency of Students Practicing English Language Skills in Classroom

The frequency of practicing listening skills delivered by teachers is an average score of 1.85 with a percentage of 46 . Thus, it can be interpreted that the frequency of students practicing listening skills in English is unfavorable to developing proficiency in aural comprehension. In speaking skills, the data showed quite a high intensity of practice, 
with the average score of 2.69 and a percentage of 67 . In writing skills, the data also indicated quite a high intensity of practice with the average score of 2.88 and a percentage of 72 . Among all the English language skills practiced in the classroom, reading was the most frequently practiced with the average score of 3.11 and a percentage of 78. Overall, the data showed that the frequency of English language skills practiced in the classroom was quite high, with an average score of 2.63 and a percentage of 65.8 .

3). The Level of Students' Difficulty with English Language Skills

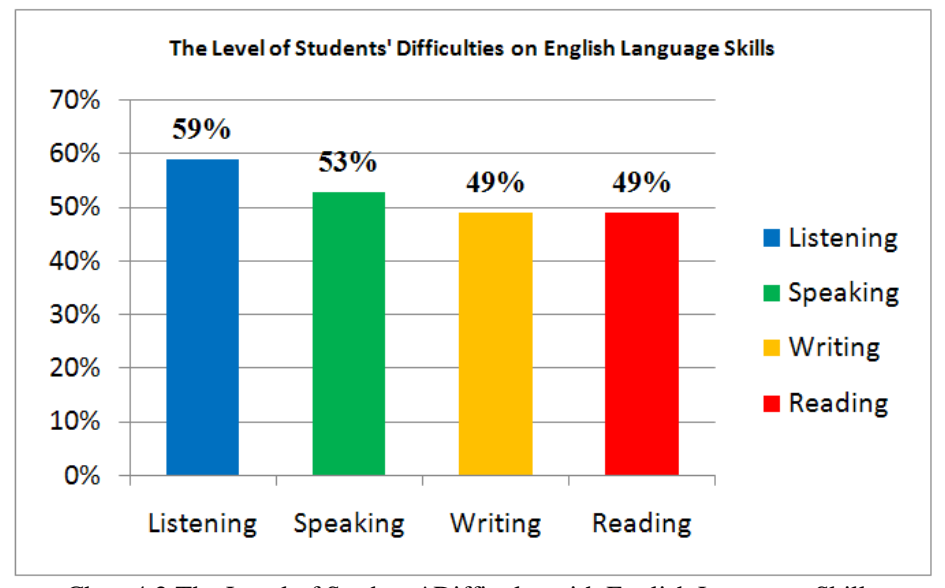

Chart 4.2 The Level of Students' Difficulty with English Language Skills

The data from chart 2 demonstrates that most of the students found all the language skills quite tricky and mainly found listening to be the most difficult. The data indicated that listening is very complicated with an average score of 2.35 and a percentage of 59. The speaking skill was also considered quite difficult with the average score of 2.12 and a percentage of 53. The writing skill and reading skill proved to be quite difficult as well with the average score of 1.97 and a percentage of 49. Overall, the level of students' difficulty toward English language skills was quite high with the average score of 2.10 and a percentage of 52.6.

4). The Importance Level of English Language Skills

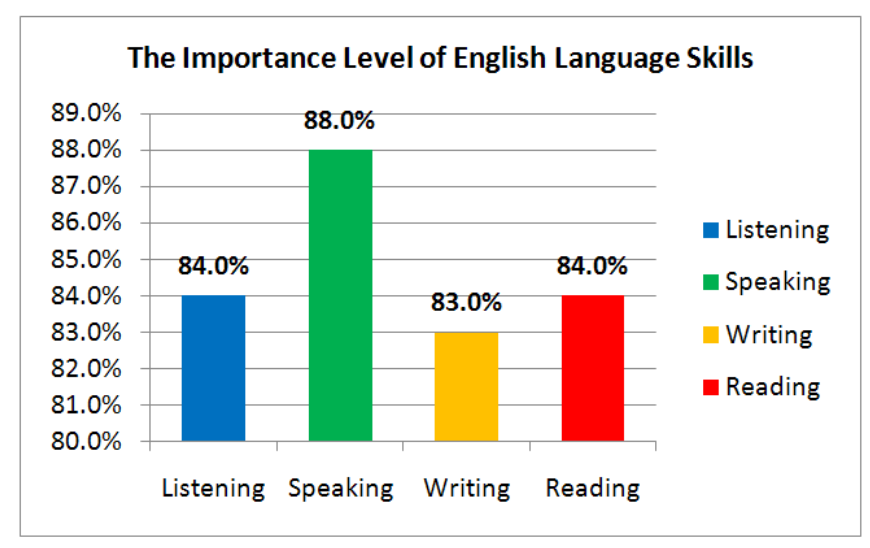

Chat 4.3 The importance level of English Language skills

The importance level of all the four language skills is considered very high according to the data acquired. Chart 3 describes the average score of all language skills in English at 3.39 with a percentage of $84.7 \%$. However, the highest rated skill was speaking with a percentage $88 \%$.

5).The participants believed that the main objectives of learning English as a general course are as follows:

\begin{tabular}{|l|c|c|}
\hline \multicolumn{1}{|c|}{ Statement } & Score & Percent (\%) \\
\hline $\begin{array}{l}\text { To improve students' readiness to be able to } \\
\text { continue their studies abroad }\end{array}$ & 45 & $69.2 \%$ \\
\hline $\begin{array}{l}\text { To improve students' ability to communicate in } \\
\text { English }\end{array}$ & 44 & $67.7 \%$ \\
\hline $\begin{array}{l}\text { To improve students' capability to comprehend } \\
\text { English literature/resources }\end{array}$ & 20 & $30.8 \%$ \\
\hline To fulfill a curriculum requirement & 14 & $21.5 \%$ \\
\hline $\begin{array}{l}\text { To enhance the likelihood of students finding a job } \\
\text { after graduation }\end{array}$ & 42 & $64.6 \%$ \\
\hline
\end{tabular}


6). The medium of instruction in the learning process

When asked what was should be the medium of instruction during the learning process, the students responded most strongly that English should be - either partly, or wholly. Meanwhile, students thought that it is less crucial for the materials to be produced in Bahasa Indonesia either entirely or partially. Most students tended to believe that it is essential to use both languages interchangeably. The data below shows students' perception of the language used in the learning process:

7). The level of importance of learning method or activities

Every student had their preference on how to acquire knowledge and learn:

\begin{tabular}{|l|c|c|c|}
\hline \multicolumn{1}{|c|}{ Learning Preference } & Average & Percent & classification \\
\hline Self-learning & 3.08 & $76.9 \%$ & Important \\
\hline Learning in couple & 3.03 & $75.8 \%$ & Important \\
\hline Small group learning & 3.11 & $77.7 \%$ & Important \\
\hline Large group learning & 2.82 & $70.4 \%$ & Important \\
\hline Audio learning & 3.09 & $77.3 \%$ & Important \\
\hline Learning by reading & 3.23 & $80.8 \%$ & Important \\
\hline Learning by listening and speaking & 3.37 & $84.2 \%$ & Very important \\
\hline $\begin{array}{l}\text { Learning by listening and speaking } \\
\text { reading material while writing }\end{array}$ & 3.14 & $78.5 \%$ & Important \\
\hline $\begin{array}{l}\text { Learning by repeating what is being } \\
\text { listened }\end{array}$ & 3.11 & $77.7 \%$ & Important \\
\hline $\begin{array}{l}\text { Learning by memorizing the } \\
\text { conversation }\end{array}$ & 2.92 & $73.1 \%$ & Important \\
\hline Learning through games and quizzes & 3.03 & $75.8 \%$ & Important \\
\hline Learning through role plays & 2.97 & $74.2 \%$ & Important \\
\hline Learning through western songs & 2.94 & $73.5 \%$ & Important \\
\hline $\begin{array}{l}\text { Average score of respondents } \\
\text { reactions }\end{array}$ & 3.06 & $76.6 \%$ & Important \\
\hline
\end{tabular}

From the above data, we can see that all the 13 learning methods and activities are proven to be important to students with the percentage of 76.6, and in particular, learning by listening and speaking, to be very important to students with the percentage over 80 .

8). Reasons for the unsatisfactory attitude towards the existing materials

\begin{tabular}{|l|c|c|}
\hline \multicolumn{1}{|c|}{ Statement } & Score & Percent (\%) \\
\hline Boring materials & 12 & $18.5 \%$ \\
\hline Irrelevant to the students' needs & 17 & $26.2 \%$ \\
\hline Irrelevant to the field of study & 8 & $12.3 \%$ \\
\hline The teaching method is boring & 19 & $29.2 \%$ \\
\hline
\end{tabular}

There are quite a few reasons why students considered the existing materials used to be unsatisfying or to fail to meet their expectations. The highest frequency of $29.2 \%$ blamed it on the annoying teaching method, followed by the irrelevance of the materials to the students' needs (26.2\%). Meanwhile, $18.5 \%$ of students expressed that the materials used in teaching General English were boring and $12.3 \%$ students stated that the materials were irrelevant to the field of study. From the table above, it can be concluded that the reason why students found the materials used currently unsatisfying is due to the university method of teaching and the irrelevancies of the materials.

9). Topics of General Maritime English 


\begin{tabular}{|l|c|c|l|}
\hline \multicolumn{1}{|c|}{ Learning Topics } & Average & Percent & Category \\
\hline $\begin{array}{l}\text { Asking for and giving } \\
\text { personal data }\end{array}$ & 3.22 & $80.4 \%$ & Important \\
\hline $\begin{array}{l}\text { Discussing navigational } \\
\text { routes }\end{array}$ & 2.94 & $73.5 \%$ & Important \\
\hline Naming type of vessel & 3.06 & $76.5 \%$ & Important \\
\hline $\begin{array}{l}\text { Describing the location and } \\
\text { purpose of safety } \\
\text { equipment }\end{array}$ & 2.88 & $71.9 \%$ & Important \\
\hline $\begin{array}{l}\text { Understanding commands } \\
\text { in emergency situations on } \\
\text { board }\end{array}$ & 3.05 & $76.2 \%$ & Important \\
\hline $\begin{array}{l}\text { Naming position on boards; } \\
\text { giving directions on board }\end{array}$ & 3.28 & $81.9 \%$ & Very Important \\
\hline $\begin{array}{l}\text { Dealing with health and } \\
\text { safety on board }\end{array}$ & 3.32 & $83.1 \%$ & Very Important \\
\hline $\begin{array}{l}\text { Telling about what's } \\
\text { happening on board and } \\
\text { around you }\end{array}$ & 3.40 & $85.0 \%$ & Very Important \\
\hline Talking about sport & 1.83 & $45.8 \%$ & Unimportant \\
\hline $\begin{array}{l}\text { Describing crew roles and } \\
\text { routines }\end{array}$ & 3.03 & $75.8 \%$ & Important \\
\hline $\begin{array}{l}\text { Discussing food on board; } \\
\text { ordering meals; reporting } \\
\text { damage to food cargoes }\end{array}$ & 3.32 & $83.1 \%$ & Very Important \\
\hline $\begin{array}{l}\text { Movies } \\
\text { Society }\end{array}$ & 1.83 & $45.8 \%$ & Unimportant \\
\hline $\begin{array}{l}\text { Talking about holidays } \\
\text { expressing personal likes } \\
\text { and dislikes }\end{array}$ & 2.77 & $65.4 \%$ & Unimportant \\
\hline $\begin{array}{l}\text { Average score of } \\
\text { respondents' reactions }\end{array}$ & 1.38 & $34.6 \%$ & Unimportant \\
\hline $\begin{array}{l}\text { Fashion } \\
\text { Other Topics: Music }\end{array}$ & $66.9 \%$ & Important \\
\hline
\end{tabular}

Students were questioned on their preferred English learning topics and were asked their opinions on 16 learning topics as to whether they considered them important or unimportant. The results reveal that there are 4 topics that students consider very important as the percentages are over 80 as follows; (i) discussing food on board; ordering meals; reporting damage to food cargoes, (ii) telling about what's happening on board and around you, (iii) naming position on boards; giving direction on board, and (iv) dealing with health and safety on board.

Asking for and giving personal data, describing crew roles and routines, understanding commands in emergency situations on board, naming the type of vessel, discussing navigational routes, and others like music and free time activities (expressing likes and dislikes) were the learning topics students considered to be important as well. However, there were 4 topics including fashion, talking about holidays, society, and talking about sport that were considered to be unimportant to students with percentages below $50 \%$.

\section{B. Discussion}

A students' needs analysis is essential to the feasibility of a product that should be measured by the demands and needs of the users. It was started by measuring the students' level of oral communication apprehension, because this is an important part of needs analysis. It is one aspect that should be identified by the researcher to inform the development of General Maritime English materials. Gardner, et.al (2005) revealed that the students' anxiety or oral communication apprehension could be minimized by certain teaching materials and learning strategies that the teachers apply in their teaching and learning process. In addition, learning English by using games and role plays was also found to be an important consideration in designing activities in the course design., for all of the respondents categorized these activities as 'important' to be used in teaching and learning English.

A modified FLCAS questionnaire is used to investigate whether students are in a high, moderate, or low apprehension classification. After the participants filled out the questionnaire, the researchers then gave them an assessment score for each question from each participant. After reviewing each participant FLCAS questionnaire, the answers to all questions were compiled to create an overall apprehension assessment using the Likert Scale described in the previous section to assess survey questions as to whether they were positive or negative.

Based on the FLCAS result, there are 89 students who felt really anxiety toward English class especially when they had speaking activity. They trembled when they knew they were going to be called in maritime English class (Aeni, 2017). It is in line with the item number 3 "I trembled when I know that I am going to be called on Maritime English class". During observations and based on the result of the questionnaire, there were two students who were indicated to be low apprehensive, supported by FLCAS results. They experienced the symptoms of apprehension only at the first time they spoke, then they could manage and control their communication in order to get a good performance. Ortega 
(2013) also states that foreign language anxiety is occurring when people feel confused, freeze up, and cannot say anything in speaking foreign language. Gibson and Hanna (2003) found that public speaking apprehension can be showed in many ways, namely: blood pressure, hand trembling, feeling apprehensive, forgetting the prepared materials, and avoiding looking at the audience. The students still showed the symptoms of apprehension such as many fillers and mumbling. Although they looked very anxious at the beginning of speaking test, they still can mitigate their anxiety with some strategies such as smiling, pause, deep breathing, and some gestures.

In this stage, the researcher analyzes the students wants, necessities and lacks. She also analyzes the existing syllabus, lesson plan, course materials used in teaching Maritime English at Akademi Maritim Indonesia AIPI Makassar. The researcher tries to find the present condition of students' ability in learning English and their expectation as well. This includes, their goals in learning English, how they think English materials should delivered in terms of language orientation, the learning topics, and their learning preferences.

The current condition of the teaching of the General Maritime Course at Akademi Maritim Indonesia AIPI is very important. Current teaching methods show that the students English language skills in the classroom is still low, especially in listening and speaking skills. However, students are aware of the importance of developing these particular language skills (percentage of 84.7). However, the results show that current teaching methods and materials have not yet improved students' achievement in four sufficient language skills. Proven by the fact that many students still consider the four language skills to be too complicated. Most of teaching and learning processes are dominated by teachers' talking about grammar or asking students to write, and the lack of motivating the students to speak. Moreover, students' needs and expectation toward the comfortable and interactive teaching and learning process are being ignored. As shown in the students' needs analysis, they are expecting the materials designed to involve them and give them more opportunities for speaking activities. Students stated their primary objective in learning English was for enhancing their ability in communication, as one of the essential qualifications for seeking jobs. If they had more opportunity to practice speaking in the classroom, it would likely lead to less anxiety and better performance when their speaking skills were precisely tested. However, currently, they are being tested for something that they have not been adequately prepared.

\section{CONCLUSION}

The present condition of the students' level of oral communication apprehension is generally high. This is connected to the present teaching and learning method in the General Maritime English course implemented at the Akademi Maritim Indonesia AIPI Makassar which shows inadequacy in fulfilling students' needs and expectations. Most of the students assumed that the four language skills (listening, speaking, reading, and writing) in English are crucial, but they put productive skills (writing and speaking) as the highest priority. Based on the data, the students requested materials that can prepare them to have good communication skills. This would not only prepare them for their oral tests, but more importantly to be able to work effectively in the international maritime industry once graduated. One immediate result of this research was the primary researcher's subsequent development of new teaching and learning materials such as a syllabus, lesson plans, and a course book designed specifically for the Maritime students of Makassar, South Sulawesi.

\section{ACKNOWLEDGEMENTS}

The researchers address thanks to the Directorate General of Research Enhancement and Development, Ministry of Research, Technology, and Higher Education of Indonesia for the financial support (State University of Makassar, Northern Illinois University and AMI AIPI Makassar).

\section{REFERENCES}

[1] Aeni, N., Jabu, B., Rahman, M. A., \& Strid, J. E. (2017). English Oral Communication Apprehension in Students of Indonesian Maritime. International Journal of English Linguistics, 7(4), p.158-167.

[2] Atmowardoyo, H. (2018). Research Methods in TEFL Studies: Descriptive Research, Case Study, Error Analysis, and R \& D. Journal of Language Teaching and Research, 9(1), p.197-204.

[3] Bin-Tahir, S. Z., Atmowardoyo, H., Dollah, S., \& Rinantanti, Y. (2017). Multilingual learning program: pesantren students' perceptions of the multilingual simultaneous-sequential model. JELE (Journal of English Language and Education), 3(2), p.4453.

[4] Bin-Tahir, S. Z., Atmowardoyo, H., Dollah, S., \& Rinantanti, Y. (2017). Multilingual Instructional Model of Pesantren Schools in Indonesia. Journal of Language Teaching and Research, 8(6), p. 1210-1216.

[5] Croucher, SM. (2015). A Cross-Cultural Analysis of Communication Apprehension. Journal of Intercultural Communication, ISSN 1404-1634, issue 38, July (2015). URL: http://immi.se/intercultural. Accessed on January 2016.

[6] Dirgayasa, I. W. (2014). Survey of English Teaching and Learning Process in Maritime Education and Training in Indonesia: A Case Study in Private MET in Indonesia. English Language Teaching, 7(7), p.111-120.

[7] Embassy of the Republic of Indonesia. (2014). Indonesian archipelago. Retrieved on $11^{\text {th }}$ June, 2017 from http://www.indonesia.hu/page.php?id=99\&titlethearchipelago.

[8] Evans, T. D., \& St John, M. J. (2001). Developments in ESP: A Multi-disciplinary Approach. New York: Cambridge University Press.

[9] Fan, L. (2017). An Overview of Chinese Seafarers' Communicative Competence in English—Chinese Seafarers' Perspectives. 
TransNav, the International Journal on Marine Navigation and Safety of Sea Transportation, 11(4). P. 577-581.

[10] Fan, L., Fei, J., Schriever, U., \& Fan, S. (2017). The communicative competence of Chinese seafarers and their employability in the international maritime labour market. Marine Policy, 83, p.137-145.

[11] Gardner, C. T., Milne, M. J., Stringer, C. P., \& Whiting, R. H. (2005). Oral and written communication apprehension in accounting students: Curriculum impacts and impacts on academic performance. Accounting Education, 14(3), p. 313-336.

[12] Gibson, B. J., \& Hanna, J. B. 2003. Periodical usefulness: the US logistics educator perspective. Journal of Business Logistics, 24(1), p. 221-240.

[13] Hyland, K. (2006). English for academic purposes: An advanced resource book. London: Routledge.

[14] Holland, L. C. (2016). A Study of the Intelligibility, Comprehensibility and Interpretability of Standard Marine Communication Phrases as Perceived by Chinese Mariners (Doctoral dissertation, Portland State University).

[15] Hutchinson, T., \& Waters, A. (1987). English for specific purposes. Cambridge: Cambridge University Press.

[16] Khan, T. M., \& Awan, A. S. (2011). Needs Analysis of English for Occupational and Specific Purposes. International Journal of Social Sciences \& Education, 1(4), 632-643.

[17] Latifa, A., Rahman, A., Hamra, A., \& Jabu, B. (2015). Developing a Practical Rating Rubric of SpeakingTest for University Students of English in Parepare, Indonesia. English Language Teaching, 8(6), p.166-179.

[18] Leary, M. R. (2013). Social Anxiety, Shyness, and. Measures of personality and social psychological attitudes: Measures of social psychological attitudes, $1,161-176$.

[19] Liyanage, I., \& Walker, T. (2014). English for academic purposes: a trojan horse bearing the advance forces of linguistic domination?. Affirming language diversity in schools and society: Beyond linguistic apartheid, 165-175.

[20] Munby, J. (1978). Communicative syllabus design. Cambridge: Cambridge University Press.

[21] Ortega, L. 2013. SLA for the 21st century: Disciplinary progress, transdisciplinary relevance, and the bi/multilingual turn. Language Learning, 63(1), p. 1-24.

[22] Panggua, S., Wello, B., \& Macdonald, D. (2017). Self-Assessed Professional Competence of the High School EFL Teachers in Toraja Indonesia. International Journal of English Linguistics, 8(2), p.25-36.

[23] Poedjiastutie, D., \& Oliver, R. (2017). English learning needs of ESP learners: Exploring stakeholder perceptions at an Indonesian University. TEFLIN Journal, 28(1), p.1-11.

[24] Pritchard, B. (2004). A Survey of Maritime English Materials-State of the Art in Maritime English. International Association of Maritime Universities, Nippon Foundation, 1(1), p. 118-131.

[25] Rahman, M. (2015). English for Specific Purposes (ESP): A Holistic Review. Universal Journal of Educational Research, 3(1), p. 24-31.

[26] Ratnah. (2013). Developing English for Specific Purpose (ESP) Course for Tour and Travel Students Based on Needs Analysis. Unpublish Dissertation. Makassar: Graduate Program State University of Makassar.

[27] Richards, J.C. (2001). Curriculum Development in Language Teaching. New York: Cambridge University Press.

[28] Robinson,P. (1991). ESP today: a practitioner's guide. Herforshire: Prentice Hall.

[29] Sakkir, G. (2016). Interest and Writing Skill of the University Students on Using Social Media-Facebook in Writing Class (STKIP Muhammadiyah Rappang, Indonesia). In Asian EFL Journal (Second Language Acquisition-Academic Research) TESOL Indonesia International Conference Edition (Vol. 2, pp. 178-188).

[30] Salikin, H., Bin-Tahir, S. Z., Kusumaningputri, R., \& Yuliandari, D. P. (2017). The Indonesian EFL Learners' Motivation in Reading. English Language Teaching, 10(5), p. 81-90.

[31] Suriaman, A., Rahman, A., \& Noni, N. (2018). Developing Web-based English Instructional Material Oriented to Promote Independent Learning at Indonesian University Context. Journal of Language Teaching and Research, 9(2), 336-345.

[32] Tahir, S. Z. B., \& Hanapi, H. (2017). Lecturers' Method in Teaching Speaking at the University of Iqra Buru. International Journal of English Linguistics, 7(2), 73-85.

[33] West, R. (1997). Needs analysis: State of the art. Teacher education for LSP, 68-79.

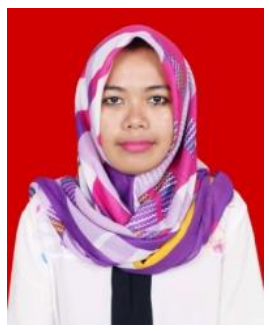

Nur Aeni M was born in Selayar, South Sulawesi, Indonesia on August $27^{\text {th }}$, 1988. She completed her undergraduate study in 2009 in English Education at Universitas Negeri Makassar. She earned her Master degree from State University of Makassar in Indonesia. Her research interest is in Teaching English as Foreign language and the use of circle games in teaching vocabulary. Shevis a lecturer at Indonesian Maritime Academy AIPI Makassar. She is currently a Ph.D student at Universitas Negeri Makassar. She attended some International Conference as the Presenter. Namely: International Conference on language education, International Conference on Education, Science, Art and Technology.

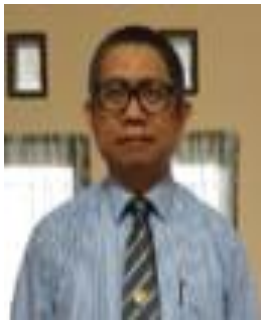

Baso Jabu completed his undergraduate studies in 1987, majoring in Teaching English as a Foreign Language (TEFL) at Ujung Pandang Institute of Teacher Training and Education (currently Universitas Negeri Makassar), Indonesia. He completed his Master's and doctoral degrees in the field of applied linguistics at Hasanuddin University in Makassar, Indonesia, in 1995 and 2007, respectively. He was awarded a Specialist Certificate in Language Testing at the Regional Language Centre Singapore in 1996. Professor Jabu is former Director of the Language Centre at Universitas Negeri Makassar, where he manages training in some foreign languages, as well as the Indonesian language for non-native speakers. He is currently as the Second Assistant Director of Pascasarjana Universitas Negeri Makassar. He is a lecturer, and has been teaching English as a foreign language at Universitas Negeri Makassar for more than 20 years. Prof. Jabu is a 
member of TEFLIN (Teaching English as a Foreign Language in Indonesia) and MLI (Indonesia Linguistic Society). His research interests are TEFL and language assessment.

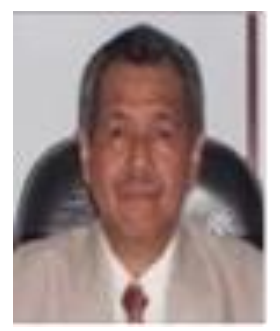

Muhammad A. Rahman was born in Selayar, South Sulawesi, Indonesia on May 21, 1952. He completed his undergraduate study in 1979 in Teaching English as a Foreign Language (TEFL) at Ujung Pandang Institute of Teacher Training and Education) in Makassar, Indonesia and master and doctorate degrees in the field of Instructional Design and Technology at the University of Pittsburgh, PA, USA in 1986 and 1990 respectively. $\mathrm{He}$ is currently a professor in the Faculty of Literature and Language, State University of Makassar, in Makassar, Indonesia. He has a lot of experience in elementary and secondary school teacher training, teacher professional development, and teaching English to young learners. He was employed for five years as ACADEMIC ADVISOR for USAID Decentralized-Basic Education leading university faculty members to develop active learning training packages for elementary school teachers. In the last couple of years, he did a research and a development study whose product is a training package for elementary school teachers of English. At present, his research focuses on module development for improving EFL college writing. He has got the Best Paper Awards on his article entitled "Reading in English as a Foreign Language: A Case of First-Year Students of Junior Secondary Schools in South Sulawesi Indonesia" from the 2nd International Conference on Theory \& Practice (ICTP-2016) of Asia Pacific Institute Advanced Research. His research interests include early reading program for learners of English as a foreign language. Prof. Rahman is a member of Indonesian Linguistics Society (MLI), Indonesian Education Scholars Association (ISPI), and TEFLIN (Teaching English as a Foreign Language in Indonesia).

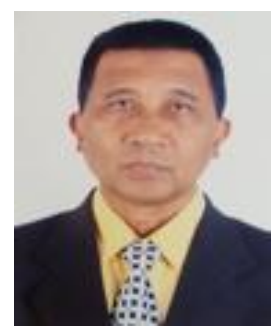

Hamid Ismail was born in Ternate, North Moluccas, Indonesia on October 5, 1961. He completed his undergraduate study in 1984 in English Education Program at Teacher Training and Education in Manado, North Sulawesi, Indonesia and Master degree in 1996 at the same field at Teacher Training and Education in Malang, East Java. He was employed for two years as committee members of Basic Education Project in North Moluccas funded by World Bank. He was to be keynote speaker on the seminar of English Teachers Forum held by West Halmahera government district. He was also to be a trainer of higher education students as a guide for foreigners in total solar eclipse in 2016 in North Moluccas province.

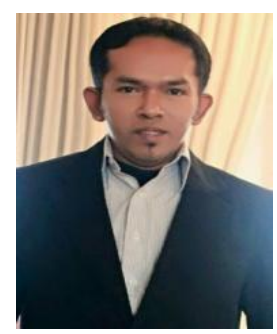

Saidna Z. Bin-Tahir is a lecturer at English Education Department of Universitas Iqra Buru, Indonesia. His areas of interest and research include teaching media, TEFL, Arabic and Linguistics, and Multilingual Education. He graduated from Al-Azhar University of Cairo in Arabic Language and Linguistics and graduated his master and doctoral degree from the State University of Makassar in English Education Department and got the short course at Northern Illinois University, USA. He has published some books and many articles in TEFL, ICT in language learning, and Multilingual teaching and learning. He had become a member of Asia TEFL, Asian EFL, International Forum of Researchers in Education (IFORE), and ADRI. He is a reviewer and editor in some local and international journals, and the head of the language center at the Universitas Iqra Buru, Indonesia. 